August 2, 1849, he was educated at Denmark Hill Grammar School, and appears to have entered at an early age into the public life of his native town. He held positions on the Board of Guardians, Local Board, Urban District Council, Hospital Board, Savings Bank, Corn Exchange, Burial Board, etc., and was created County Magistrate in 1895. On all these positions he brought to bear his geological knowledge, greatly to the advantage of his fellow-townsmen.

Mr. Hill was a Vice-President of the Geological Society of London, President of the Geologists' Association (1911-12), and had done a large amount of original work of value in the Cretaceous rocks. But the great geological work of his life was his unselfish devotion to his crippled friend Jukes-Browne. For years Hill spent week after week in the field, noting and surveying county after county and forwarding all the observations to his friend, who wrote them up for the Geological Survey memoir called The Cretaceous Rocks of Britain. Further results of this work were his brilliant addresses as President of the Geologists' Association on "Flint and Chert" and "Rocks containing Radiolaria", papers demanding not merely knowledge but technical skill and patience. William Hill died at Hitchin, November 8, 1914, and was buried there.

\title{
HENRY JAMES JOHNSTON-LAVIS, F.G.S., ETC.
}

BORN JULY 19, 1856.

Died August 10, 1914.

DR. Johnston-Lavis was born in London, July 19, 1856. On the close of his primary education at a private school he sought to enter on the medical course at the University of Montpellier. That institution, however, having had to be closed on account of a revolt of the students, he attended instead at the University of Marseilles, where he studied for a year. At the beginning of the session 1873-4 he transferred to University College, Gower street, London, and also studied some subjects at St. Mary's Hospital, Paddington. At the former institution he was placed in the First Class in Practical Chemistry in 1874, and in the First Class in Clinical Medicine in 1878. While there, also, he came under the teaching of Professor John Morris, then at his zenith, for Geology. This subject strongly attracted him and he joined the Geologists' Association in 1874, and was elected a Fellow of the Geological Society in 1875, having been by an oversight admitted before the full age. His first paper, "On the Triassic Strata which are exposed in the cliff sections near Sidmouth," was read before that Society in the following year. The bones he discovered at that locality proved to be new, and were described at the same time by Professor H. G. Seeley under the name of Labyrinthodon Lavisii. In 1876, also, he conducted evening classes in Physiology at the old Polytechnic in Regent Street. For several years he made a careful study of the Lower London Tertiaries exposed at Charlton and at Lewisham, which resulted in a paper attempting a correlation of the two sections, read before the Geologists' Association in 1877. 
After obtaining his M.R.C.S.Eng. and L.S.A. in 1878 he married Mlle. Antonia Françoise Bourdariat de Saint-Aupre, whose acquaintance he had formed when at Marseilles, and who, he testifies in the dedication to his last published work, "through a long married life encouraged me in my medical and scientific work, affording me valuable help and appreciation and aiding me to overcome almost insurmountable difficulties."

Having spent some time in 1879 as an assistant to a doctor in Plaistow, and after taking the degree of B.és Sci. Paris, he went out at the end of the sear to Naples. There he practised among the members of the English and American colonies and the visitors, and became Sanitary Director to Sir W. Armstrong's works at Puzzuoli. In 1884 he took the degree of M.D. Naples. His attention when there was early directed to the part played by Edible Mollusca in the dissemination of infectious diseases, a subject to which he recurred later. Above all it was at Naples that he was started on his vulcanological studies. To the young, energetic, and ardent geologist Vesuvius, with its many fuscinating problems, was a powerful loadstone, and consequently all his spare time was devoted to its study and survey.

His first important memoir on the subject was laid before the Geological Society in 1884. The paper was a long one and the author not then an acknowledged authority on the subject, so some condensation was insisted on before publication. Unfortunately, in his absence from England this was not too wisely or sympathetically done, and the omission of some portions spoilt the continuity of the work, a fact which involved the author subsequently in much useless discussion. The views embodied in the memoir have, however, been widely accepted on the Continent by competent authorities.

Numerous other papers on subjects connected with Vesuvins and the southern Italian volcanoes flowed from his pen during the succeeding years, including a study of, and monograph on, the great earthquake at Ischia, but his chief and perhaps most important work was the completion under great difficulties of his surrey of Vesuvius during 1880-8, and publication in 1891 of the Geological Map in six sheets on the scale of $1: 10,000$. Save for the addition of some lava streams during the eruption of 1906 there is but little to alter in the map to-day.

He became a member of the Società Geologica Italiana in 1889 , and during the autumn of that year the Geologists' Association paid a visit to the southern Italian volcanoes, mainly at the instigation of Dr. Lavis, on whom fell the brunt of the conduct of the party.

In 1890 Laris visited Iceland in company with Dr. Tempest Anderson, and his observations there were published in a paper read before the Scottish (now Royal Scottish) Geographical Society in 1895. Mention may here be also made to the joint paper with Dr. J. W. Gregory on " Eozoonal Structure of the Ejected Blocks of Monte Somma", printed in 1894, in which the authors gave the coup de grace to 'Eozoon'. He was appointed Professor (Pareg.) of Vulcanology in the Royal University of Naples in 1893, but never delivered any lectures. 
In 1892 Lavis took up a consultative practice at Harrogate for the summer season and continued this annually till 1897. Quitting Naples in 1894, he practised for one season at Monte Carlo, and then made Beaulieu his headquarters for winter seasons and permanent place of residence. In order to qualify for the exercise of his profession in France he had to go through the medical course again, and he took his M.D. at Lyons in 1895, his thesis being a complete résumé of the part played by Edible Mollusca in the propagation of gastro-intestinal diseases.

His activities, however, were by no means confined to the immediate surroundings of Beaulieu, and he took a leading part in the foundation, mainly by the financial aid of Sir John Blundell Maple, of the Queen Victoria Memorial Hospital at Nice, of which he was senior Consulting Physician.

Becoming the English Consulting Physician to the celebrated Etablissement at Vittel (Vosges), France, about 1904, he continued his summer practice there till the present year. On the outbreak of the War he dismissed his patients and started on August 1 to join his invalid wife near Château Thierry (Aisne), thence went on to Paris, and finally journeyed south, intending to reach Beaulieu by acircuitous and safe route. Unfortunately the whole journey from the very start from Vittel was attended by misadrentures, which culminated on Angust 10 in the overset of the motor-car in which they were travelling, near Bourges (Cher). The rest of the party escaped with a shaking, but Lavis himself was pinned beneath the car and killed apparently instantaneously.

Although endowed with seemingly inexhaustible energy, it was still wonderful how much he accomplished without relaxing for a moment the scrupulous and unwearied attention he devoted to his very numerous patients. More than 160 books, memoirs, etc., including many important medical theses and articles, in addition to numerous vulcanological writings, stand to his credit; whilst his latest important 'memoir was On the effects of Volcanic Action in the production of Epidemic Diseases in the Animal and Vegetable Creation, etc. (1914), which gained the Parkin Prize of $£ 100$ triennially offered by the Royal College of Physicians of Edinburgh.

A man of wide interests, practical ever, rather than what is known as scholarly, he numbered amongst his other pursuits a wide acquaintanceship with ecclesiastical architecture, and the carved woodwork in the little English Protestant church at Vittel was executed by local workmen from his exceedingly tasteful and in some respects unique designs.

Never a moment seemed wasted by him. The odd minutes were devoted to looking after the fittings and furnishing of his laboratory or of his museum, in examining and cataloguing new accessions to his vulcanological library, or in framing after a method of his own some one or other of the valuable engravings he had acquired relating to his favourite subject.

His loss will be greatly deplored not only by his bereaved family, but also by a very wide circle of friends. 